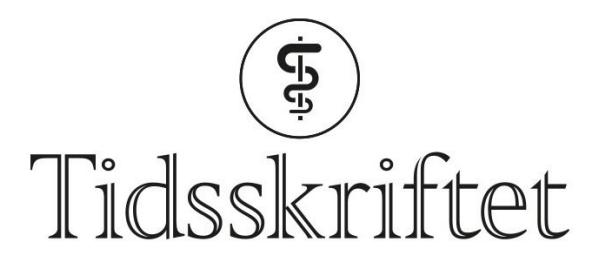

DEN NORSKE LEGEFORENING

\title{
Carotisstenose opereres ofte for sent
}

FRA ANDRE TIDSSKRIFTER

JON MAGNUS HAGA

Tidsskriftet

Tidlig carotiskirurgi, helst innen to uker etter hjerneslag, reduserer risiko for ny blodpropp hos pasienter med carotisstenose. I Norge drøyer behandlingen ofte lenger.

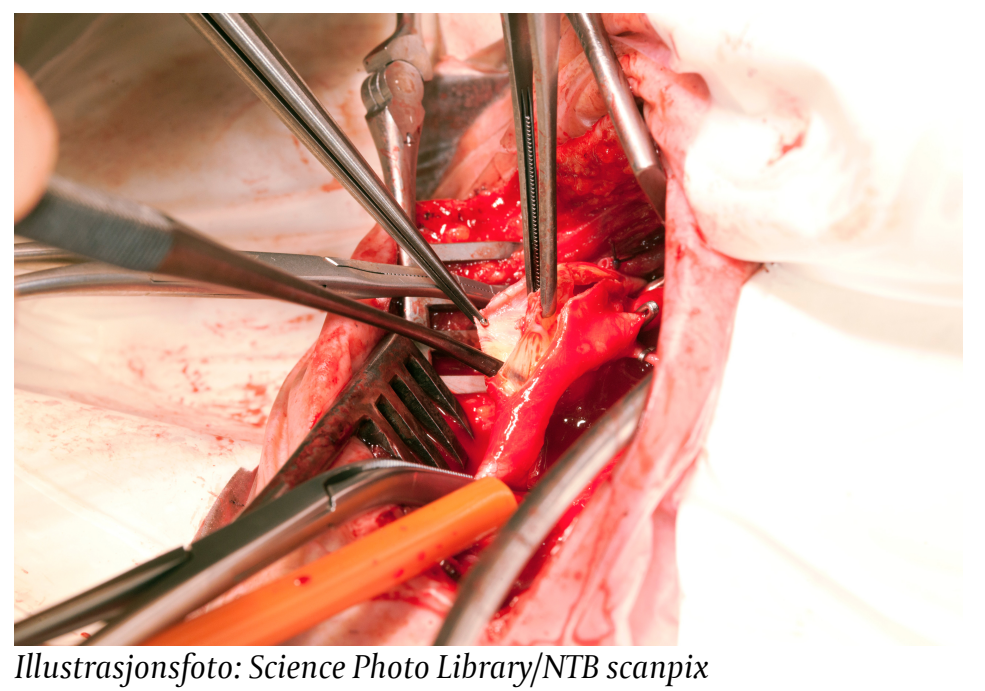

Carotisstenose er en vanlig årsak til hjerneslag. Carotiskirurgi i form av carotisendarterektomi vil redusere risikoen for blodpropp. Internasjonale retningslinjer anbefaler carotiskirurgi innen 14 dager hos pasienter som har fått påvist carotisstenose i forbindelse med hjerneslag eller transitorisk iskemisk anfall (TIA).

Carotiskirurgi utføres i dag ved 15 norske sykehus. I en studie ved disse sykehusene ble tid fra symptomdebut til kirurgisk behandling hos alle henviste pasienter gjennom ett år registrert, totalt 368 pasienter (1). Median tid fra symptomdebut til kirurgisk behandling var 11 dager. Til sammen ble rundt $62 \%$ av pasientene operert innen to uker. Senere behandling skyldtes oftest at pasienten hadde ventet lenge med å oppsøke lege og lang tid fra mottak på sykehus til behandling. 12 pasienter fikk en ny blodpropp i løpet av ventetiden.

- Denne studien viser at nær $40 \%$ av de opererte pasientene ikke ble operert innen anbefalt tid og dermed utsatt for økt risiko for nytt hjerneslag, sier Knut E. Kjørstad, som er avdelingsoverlege ved Universitetssykehuset Nord-Norge (UNN) og leder av studien.

- Kunnskapen om symptomer på hjerneslag og TIA i befolkningen må bedres, og pasientforløpet i sykehusene må bli bedre for at vi skal nå målet om best mulig behandling 
for pasienter med hjerneslag, sier han.

\section{Om forskningen}

Forskningen er et samarbeidsprosjekt mellom norske sykehus som utfører carotisendarterektomi og Norsk karkirurgisk forenings forskningsutvalg. Studien ble ledet av Knut E. Kjørstad ved Universitetssykehuset Nord-Norge og er gjennomført med støtte fra UNIKARD og Den norske legeforenings fond for kvalitet og pasientsikkerhet.

LITTERATUR:

1. Kjørstad KE, Baksaas ST, Bundgaard D et al. Editor's Choice - The National Norwegian Carotid Study: Time from Symptom Onset to Surgery is too Long, Resulting in Additional Neurological Events. Eur J Vasc Endovasc Surg 2017; 54: 415 - 22. [PubMed][CrossRef]

Publisert: 8. januar 2018. Tidsskr Nor Legeforen. DOI: 10.4045/tidsskr.17.0994

(C) Tidsskrift for Den norske legeforening 2020. Lastet ned fra tidsskriftet.no 